\title{
UPAYA MENINGKATKAN HASIL BELAJAR SISWA DENGAN \\ MENGGUNAKAN MODEL PEMBELAJARAN KOOPERATIF \\ TIPE NUMBERED HEAD TOGETHER PADA MATA PELAJARAN \\ IPADI KELAS IV SDN NO 023905 BINJAI
}

\section{OLEH: \\ RINCI SIMBOLON \\ (DOSEN PGSD FKIP UNIVERSITAS QUALITY)}

\begin{abstract}
This research is Classroom Action Research (CAR). This study aims to determine the Improvement of learning outcomes and the implementation of learning using the NHT type cooperative learning model. The location of the study was carried out at SDN No. 023905 Binjai with the research subjects being class IV students 25 people. The time of the study is conducted in the odd semester of the 2018/2019. The research was conducted in two cycles. Data collection techniques used were tests and observation sheets.

Observation results of the implementation of learning on the first cycle of teachers with a percentage of $60 \%$ with sufficient categories and the results of observation of the implementation of learning activities for students with a value of 68 with sufficient categories. The completeness of learning outcomes in cycle I was 15 students $(60 \%)$, while students who did not complete were 10 students percentage $(40 \%)$. In the second cycle the results of the observation of the implementation of learning on teachers with a percentage of $71.4 \%$ with good categories and observation of learning activities on students with a percentage of 80 with good categories. Student learning completeness in the second cycle was 22 students with a percentage $(88 \%)$, while the ones that did not complete were 3 students with a percentage $(12 \%)$.

Based on the results of the analysis it can be concluded that there is an increase in learning outcomes using the cooperative type NHT model in grade IV SDN No. 023905 Binjai.
\end{abstract}

Keywords: Learning Outcomes, NHT type cooperative learning model. 


\section{PENDAHULUAN}

IPA (Sains) merupakan cara mencari tahu tentang alam secara sistematik untuk menguasai pengetahuan, fakta -fakta, konsep-konsep, prinsip-prinsip, proses penemuan dan memiliki sikap ilmiah. IPA umumnya memiliki peran penting dalam peningkatan mutu pendidikan, khususnya dalam menghasilkan peserta didik yang berkualitas, yaitu manusia yang mampu berfikir kritis, kreatif logis dan berinisiatif dalam menanggapi isu di masyarakat yang diakibatkan oleh dampak perkembangan IPA dan teknologi.

Slameto (2003:1) mengungkapkan, bahwa guru yang menggunakan metode ceramah saja mengakibatkan siswa menjadi bosan, mengantuk, pasif, dan hanya mencatat saja. Adanya pendapat tersebut akan berpengaruh terhadap prestasi belajar IPA siswa dan secara tidak langsung akan mempengaruhi keberhasilan pelajaran IPA. Agar proses belajar mengajar di SD dapat berjalan dengan optimal maka guru harus cermat memilih model pembelajaran yang mampu membangkitkan minat belajar siswa pada mata pelajaran IPA yang diajarkan kepada peserta didik. Namun pada kenyataannya berdasarkan hasil informasi yang didapatkan dari Kepala Sekolah SDN NO 023905 binjai, kesulitan dan kendala yang dihadapi guru maupun siswa dalam proses pembelajaran IPA masih saja terjadi, belum di peroleh hasil yang maksimal. Hal ini terlihat jelas dari 25 jumlah siswa kelas IV SD yang terdiri dari 10 orang siswa laki-laki dan 15 orang siswa perempuan rata-rata nilai siswa masih belum mencapai KKM yang ditentukan sekolah yaitu 65. Dari 25 siswa yang tuntas hanya $20 \%$ sedangkan yang tidak tuntas $80 \%$. Dari fakta tersebut diketahui bahwa siswa masih mengalami kesulitan dalam belajar IPA. Hasil belajar siswa yang kurang maksimal, ada beberapa faktor penyebab proses belajar kurang maksimal, diantaranya pembelajaran IPA dianggap sulit, membingungkan serta membosankan dan kurang menarik sehingga menyebabkan siswa kurang aktif dalam mengikuti proses pembelajaran.

Model pembelajaran yang dilaksanakan guru berlangsung satu arah dan kurang bervariasi sehingga suasana kelas selama pembelajaran terlihat kurang kondusif. Melihat hal tersebut di atas maka peran guru sebagai salah satu faktor 
yang berpengaruh terhadap hasil belajar, hendaknya menjadi motivator bagi siswa karena ada kecenderungan jika siswa menyukai guru yang mengajar, maka kemungkinan hasil belajar siswa akan lebih baik, oleh karena itu guru harus mampu mengusahakan siswa senang serta berinteraksi dengan baik saat pembelajaran berlangsung, maka guru harus mampu menggunakan model yang baik dalam pembelajaran untuk mencapai hal demikian perlu diperhatikan bahwa tidak semua materi pelajaran IPA dapat disajikan dengan satu media, tetapi beberapa materi membutuhkan suatu pengamatan agar nantinya siswa dapat lebih memahami materi yang dipelajari, untuk memicu hal ini perlu disajikan suatu cara atau model yang bervariasi dan tepat sehingga dapat merangsang dan menarik bagi siswa untuk aktif belajar.

Berdasarkan permasalahan tersebut maka upaya peningkatan hasil belajar siswa merupakan masalah yang harus ditanggulangi. Salah satu upaya yang dapat dilakukan untuk mengatasi hal tersebut diperlukan suatu model pembelajaran yang tepat dan menarik untuk memperbaiki proses pelaksanaan pembelajaran. Dengan menggunakan model pembelajaran pada saat proses pembelajaran diharapkan mampu meningkatkan motivasi siswa dalam belajar, sehingga hasil belajarnya dapat menjadi lebih baik. Salah satu model pembelajaran yang dapat meningkatkan hasil belajar siswa adalah Numbered Head Together

\section{METODOLOGI PENELITIAN}

Penelitian ini dilakukan dengan menggunakan jenis penelitian tidakan kelas (PTK). Subjek penelitian ini adalah seluruh siswa kelas IV SDN No 023905 Binjai. Prosedur penelitian dilakukan menggunakan metode penelitian tindakan kelas, maka penelitian ini memiliki tahap-tahap penelitian yang berupa siklus. Jika pada siklus pertama hasil belajar siswa tidak sesuai dengan yang diharapkan, maka dilakukan siklus berikutnya. Tetapi jika dalam satu siklus hasil belajar sudah meningkat maka tidak perlu melakukan siklus berikutnya. Prosedur penelitian memiliki empat tahap yaitu: (1) perencanaan; (2) pelaksanaan; (3) pengamatan, dan (4) refleksi. Untuk pengumpulan data dalam penelitian ini, alat pengumpulan data yang digunakan adalah Observasi dan tes. 
Analisis data dilakukan melalui tiga tahap yaitu: reduksi data, paparan data, dan peyimpulan data. Untuk mengetahui tingkat kemampuan siswa yang diperoleh dari hasil belajar secara individu menggunakan rumus (Sudijono, 2008:318).

$$
\mathrm{KB}=\frac{B}{N} \mathrm{X} 100
$$

Dimana :

KB : Ketuntasan Belajar (Nilai)

B : : Skor yang diperoleh (Skor mentah)

$\mathrm{N} \quad$ : Skor Total (Skor maksimum ideal)

Untuk mengetahui persentase siswa yang sudah tuntas belajar secara klasikal digunakan rumus (Zainal Aqib, 2010:41).

$$
\mathrm{PKK}=\frac{T}{N} \times 100 \%
$$

Dimana:

PKK :Persentase Keberhasilan Klasikal

$\mathrm{T} \quad$ : Banyak siswa yang $\mathrm{KB} \geq 65$

$\mathrm{N} \quad$ : Banyak subjek penelitian

Untuk mengetahui nilai rata-rata siswa, maka rumus yang digunakan adalah rumus (Zainal Aqib, 2010:40).

Nilai rata-rata $=\frac{\text { Jumlah semua nilai siswa }}{\text { Jumlah siswa }}$

Hasil observasi aktivitas guru dan siswa dihitung dengan menggunakan rumus:

Nilai $=\frac{\text { Jumlah skor yang didapat }}{\text { jumlah skor maksimal }} \times 100$ (Jainab, 2015:108)

Setiap siswa dikatakan tuntas belajarnya (ketuntasan individu) jika proporsi jawaban benar siswa mencapai nilai KKM yang ditetapkan sekolah yaitu 65 . Depdikbud dalam Trianto (2016:241) "Suatu kelas dikatakan tuntas belajarnya 
(ketuntasan klasikal) jika dalam kelas tersebut terdapat $\geq 85 \%$ siswa yang telah tuntas belajarnya".

\section{HASIL DAN PEMBAHASAN}

\section{Hasil}

Tabel Hasil Observasi Aktivitas Guru Siklus I dan Siklus II

\begin{tabular}{|c|c|c|c|c|}
\hline No & Siklus & Skor & Persentase (\%) & Kriteria \\
\hline 1 & Siklus I & 600 & 60 & Cukup \\
\hline 2 & Siklus II & 714 & 71,4 & Baik \\
\hline
\end{tabular}

Tabel Hasil Observasi Aktivitas Siswa Siklus I dan Siklus II

\begin{tabular}{|c|c|c|c|c|}
\hline No & Siklus & Skor & Nilai & Kriteria \\
\hline 1 & Siklus I & 34 & 68 & Cukup \\
\hline 2 & Siklus II & 40 & 80 & Baik \\
\hline
\end{tabular}

Tabel Rekapitulasi Hasil Belajar Siswa pada Siklus I dan Siklus II

\begin{tabular}{|c|c|c|c|}
\hline No urut Siswa & Siklus I & Siklus II & Keterangan \\
\hline 01 & 66,15 & 76,92 & Tuntas \\
\hline 02 & 73,84 & 76,92 & Tuntas \\
\hline 03 & 67,69 & 72,30 & Tuntas \\
\hline 04 & 66,15 & 70,76 & Tuntas \\
\hline 05 & 55,38 & 69,23 & Tidak Tuntas \\
\hline 06 & 56,92 & 55,38 & Tuntas \\
\hline 07 & 46,15 & 69,23 & Tuntas \\
\hline 08 & 55,38 & 69,23 & Tidak Tuntas \\
\hline 09 & 46,15 & 55,38 & Tuntas \\
\hline 10 & 55,38 & 69,23 & Tuntas \\
\hline 11 & 73,84 & 76,92 & Tuntas \\
\hline 12 & 56,92 & 67,69 & Tuntas \\
\hline 13 & 73,84 & 80 & Tuntas \\
\hline 14 & 67,69 & 72,30 & Tuntas \\
\hline 15 & 56,92 & 66,15 & Tidak Tuntas \\
\hline 16 & 46,15 & 67,69 & Tuntas \\
\hline 17 & 32,30 & 46,15 & Tuntas \\
\hline 18 & 66,15 & 67,69 & 83,07 \\
\hline 19 & 80 & & \\
\hline & & & \\
\hline
\end{tabular}




\begin{tabular}{|c|c|c|c|}
\hline 20 & 80 & 83,07 & Tuntas \\
\hline 21 & 66,15 & 70,76 & Tuntas \\
\hline 22 & 69,23 & 66,15 & Tuntas \\
\hline 23 & 67,69 & 66,15 & Tuntas \\
\hline 24 & 73,84 & 76,92 & Tuntas \\
\hline 25 & 84,61 & 87,69 & \\
\hline Nilai Rata-rata & 62,35 & 70,08 & \\
\hline $\begin{array}{l}\text { Siswa yang } \\
\text { Tuntas yang }\end{array}$ & $15(60 \%)$ & $22(88 \%)$ & \\
\hline $\begin{array}{l}\text { Siswa yas } \\
\text { Tidak Tuntas }\end{array}$ & $10(40 \%)$ & $3(12 \%)$ & \\
\hline
\end{tabular}

\section{Pembahasan}

Penelitian Tindakan Kelas (PTK) ini dilaksanakan di sekolah SDN No 023905.

PTK ini dilaksanakan sebanyak 2 siklus. PTK ini dilaksanakan 2 siklus karena pada siklus I peneliti belum mencapai ketuntasan secara klasikal. Ketuntasan klasikal pada siklus I hanya $60 \%$ saja. Pada siklus II hasil belajar siswa secara individu telah mengalami peningkatan yaitu siswa yang tidak tuntas hanya 3 (12\%) orang dari jumah 25 orang siswa. Siswa yang tuntas sebanyak 22 orang $(88 \%)$.

1. Pelaksanaan pembelajaran pada siklus I dan siklus II adalah sebagai berikut:

a. Dari hasil observasi proses pembelajaran oleh observer melalui lembar obeservasi bahwa pelaksanaan pembelajaran belum maksimal yang dilakukan oleh guru dalam melaksanakan PTK dengan persentase siklus I untuk aktivitas guru $60 \%$ (berkategori cukup) dan aktivitas siswa 68 ( berkategori cukup).

b. Sedangkan untuk siklus II hasil observasi pada aktivitas guru memperoleh 71,4\% (berkategori baik) dan untuk aktivitas siswa 80 (berkategori baik) 
2. Ketuntasan belajar siswa pada siklus I dan siklus II adalah sebagai berikut:

a. Ketuntasan hasil belajar siswa secara individu pada siklus I bahwa dari 25 siswa hanya 15 orang siswa yang tuntas belajar, dan siswa yang tidak tuntas sebanyak 10 orang siswa. Kemudian ketuntasan hasil belajar siswa secara klasikal pada siklus I adalah 60\% siswa yang tuntas belajar, dan siswa yang tidak tuntas sebanyak $40 \%$, dan rata-rata kelas hasil belajar siswa adalah 62,35 .

b. Ketuntasan hasil belajar siswa secara individu pada siklus II bahwa dari 25 siswa terdapat 22 orang siswa yang tuntas belajar dan siswa yang tidak tuntas belajar sebanyak 3 orang siswa. Kemudian ketuntasan hasil belajar siswa secara klasikal pada siklus II adalah siswa yang tuntas belajar sebanyak $88 \%$ dan siswa yang tidak tuntas belajar sebanyak 12\%. Dan rata-rata kelas hasil belajar siswa adalah 70,08 .

Upaya yang dilakukan untuk meningkatkan hasil belajar siswa adalah melakukan kegiatan pembelajaran dengan memperhatikan kelemahan-kelemahan yang dialami selama siklus I. Dari hasil tindakan pada siklus II diperoleh bahwa pada siklus II terdapat 22 orang siswa dengan persentase $88 \%$ mendapat nilai tuntas dan 3 orang siswa dengan persentase $12 \%$ mendapat nilai tuntas dengan rata-rata 70,08. Itu artinya pembelajaran sudah mencapai tingkat ketuntasan yang telah ditetapkan. Oleh karena itu tidak perlu dilanjutkan pada siklus berikutnya. Dengan demikian hipotesis tindakan yang diajukan dalam penelitian ini sesuai dengan pernyataan bahwa dengan menggunakan Model Pembelajaran Numbered Head Together dapat meningkatkan hasil belajar siswa pada mata pelajaran IPA. 


\section{PENUTUP}

\section{SIMPULAN}

Berdasarkan hasil belajar IPA dan pelaksanaan penelitian tindakan kelas (PTK) yang dilakukan dengan menggunakan metode NHT pada siswa kelas III SDN No 023950 Binjai dapat disimpulkan sebagai berikut :

1. Pelaksanaan pembelajaran melalui penggunaan metode NHT dengan baik. Hal ini dapat dilihat dari hasil observasi aktivitas guru yang berkategori cukup menjadi baik dan aktivitas siswa dari kategori cukup menjadi baik.

2. Pembelajaran melalui penggunaan metode pembelajaran dapat meningkatkan hasil belajar IPA pada siswa kelas IV SDN No 23950 Binjai.

\section{DAFTAR PUSTAKA}

Ahmad Susanto. 2016. Teori Belajar \& Pembelajaran. Jakarta: Prenada Media Group..

Asep Jihad dan Abdul Haris 2013. Evaluasi Pembelajaran. Yogyakarta: Multi Pressindo.

Dimyati. 2013. Belajar dan Mengajar. Jakarta: Rineka Cipta.

Istarani. 2012. 58 Model Pembelajaran Inovatif. Medan: Media Pers.

Ngalimun. 2014. Strategi dan Model Pembelajaran. Yogyakarta. Aswaja Presindo.

Oemar Hamalik. 2014. Kurikulum dan Pembelajaran.Jakarta : Bumi.

Rusman. 2014. Model-Model Pembelajaran. Jakarta: PT Raja Grafindo Persada.

Sagala, Syaiful. 2013.Konsep dan Makna Pembelajaran. Bandung: Alfabeta.

Slameto. 2016. Belajar \& Faktor-Faktor Yang Mempengaruhi. Jakarta: PT. Rineka Cipta.

Sudjana. 2013. Penilaian Hasil Proses Belajar Mengajar. Bandung : Remaja Rosdakarya.

Sudjana. 2016. Metode Statistika. Bandung: PT Tarsito.

Suharsimi Arikunto dkk. 2014. Penelitian Tindakan Kelas. Jakarta: Bumi Aksara. Sumiati,dkk. 2016. MetodePembelajaran. Bandung: Wacana Prima. 
Trianto. 2016. Mendesain Model Pembelajaran Inovatif Progresif. Jakarta:

Kencana Prenada Media Group.

Zainal Aqib dkk. 2014. Penelitan Tindakan Kelas. Bandung: CV.Yrama Widya. 